\title{
Evaluation of the hand anthropometric measurement in ADHD children and the possible clinical significance of the $2 \mathrm{D}: 4 \mathrm{D}$ ratio
}

\author{
Ece Buru' ${ }^{1^{\star}}$, Rabet Gözil' ${ }^{2}$, Meltem Bahçelioğlu ${ }^{3}$, Seçil Özkan ${ }^{4}$, Elvan İşeri ${ }^{5}$ \\ ${ }^{1}$ Department of Anatomy, Faculty of Medicine, Van Yuzuncu Yil University, Van, Turkey \\ ${ }^{2}$ Department of Anatomy, Faculty of Medicine, Yuksek Ibtisas University, Ankara, Turkey \\ ${ }^{3}$ Department of Anatomy, Faculty of Medicine, Gazi University, Ankara, Turkey \\ ${ }^{4}$ Department of Public Health, Faculty of Medicine, Gazi University, Ankara, Turkey \\ ${ }^{5}$ Department of Child and Adolescent Psychiatry, Faculty of Medicine, Gazi University, Ankara, Turkey
}

\begin{abstract}
Attention deficit/hyperactivity disorder (ADHD) is characterized with decreased storage time of the information related to the lack of attention and behavioral changes such as hyperactivity and anxiety with hand features. Our purpose was to investigate the possibility to use the $2 \mathrm{D}: 4 \mathrm{D}$ ratio in clinics as an easy prediagnostic parameter.

A total of 540 people (104 ADHD, 436 controls) between 7-17 years old were included in our study.

Our study group revealed a statistically meaningful difference between the ADHD and their controls in 2D:4D ratio of their right hand and the 2D:4D and 4D:5D ratios of their left hand. The male ADHD subjects and controls also demonstrated significant difference in their $2 \mathrm{D}: 4 \mathrm{D}, 2 \mathrm{D}: 5 \mathrm{D}, 3 \mathrm{D}: 4 \mathrm{D}$, and 3D:5D ratios of the right hand and the $2 \mathrm{D}: 4 \mathrm{D}$ and $2 \mathrm{D}: 5 \mathrm{D}$ ratios of the left hand. Especially, ADHD boys had a more feminized 2D:4D left hand ratio than the controls. While, there was a significant difference in all finger ratios of the right hand and the $2 \mathrm{D}: 4 \mathrm{D}$ and $4 \mathrm{D}: 5 \mathrm{D}$ ratios of the left hand between the ADHD girls and their controls. Thus, the more masculine 2D:4D right hand ratio was observed in ADHD girls.

Our results pointed out that the ADHD and some other child psychiatric disorders could be early diagnosed related to the anthropologic parameters. So, the treatment of these individuals could be assigned in early period.
\end{abstract}

Key Words: 2D:4D ratio, ADHD, hand anthropometry, finger length ratios, child

\section{Introduction}

The shape and the different anatomical parts of the hand are forming an overall picture of the developmental characteristics of the human. The genetic factors influence the hand's development, but also psychological and physiological factors can change its special features (1).

Many studies so far have reported that Hox (homeobox) gene family affects embryological development of urogenital system, fingers, and testes. This gene family includes HOX-1, HOX-2, HOX-3, and HOX-4 complexes. It is known that high testosterone levels may alter the effects of this gene family. Under the light of this information, it is considered that Hox gene family, other genetic factors, sex, race, and intrauterine gonadal hormones especially high intrauterine testosterone levels - play a role in development of ADHD and variations in hand measurements (2-5). Meanwhile, a recent study revealed the influence of prenatal testosterone (PT) and prenatal estrogen (PE) on developing digit primordia of the mouse in a narrow time window of the embryological life, using an early molecular marker (Sox9) (6).

The proportions of the human hand and its different parts-length and width of the hand, length of each digit - have been measured separately using several reference points as a criteria (7). In normal anatomical structure, $2 \mathrm{D}: 4 \mathrm{D}$ ratio is higher or equal to 1 in females $(p \geq 1)$ and lower to 1 in males $(p<1)$ (8). Females usually have a longer second finger than fourth finger (2D:4D $\geq 1$ ) (8). Males, on the other hand, have a longer fourth finger than second finger $(2 \mathrm{D}: 4 \mathrm{D} \leq 1)$ (8). Attention deficit / Hyperactivity disorder (ADHD) has been reported having important influence on hand morphometry $(9,10)$. Finger measurements in children with attention deficit and hyperactivity disorder have revealed that this ratio may be associated with different symptoms in both gender (11). A low 2D:4D ratio found to be correlated with hyperactivity and poor social cognitive

This study was performed in 16th National Anatomy Congress / poster session (Publication number:3465692) Evaluation of the hand anthropometric measurement in ADHD children and the possible clinical significance of the 2D:4D ratio (2014)

*Corresponding Author: Ece Buru, Department of Anatomy, Faculty of Medicine, Van Yuzuncu Yil University, Van, Turkey Phone: +90 43221504 72, E-mail: buruecebiber@gmail.com, eceburu@yyu.edu.tr

Received: 08.09.2017, Accepted: 12.09.2017 
function in girls while a high 2D:4D ratio was more associated with emotional symptoms in boys (11). This condition is not only observed in ADHD, but also in other psychiatric diseases of childhood such as autism, Asperger syndrome or on male adult physical aggression $(12,4)$. Especially, the relative lengths of the second to fourth digits (2D:4D) have been found to be strongly correlated with ADHD/Combined symptoms in females of a college sample population but they also reported other correlations between the Wender Utah Rating Scale and other digits ratios in both gender (13). While, McFadden et al. (14) have also found significant differences for 2D:5D, 3D:5D and $4 \mathrm{D}: 5 \mathrm{D}$ ratios between $\mathrm{ADHD} /$ Inattentive boys and controls than the 2D:4D ratio.

Genes previously investigated as the genetic cause of attention deficit and hyperactivity disorder include thyroid receptor beta gene, dopamine receptor genes, dopamine D2 receptor genes (DRD2), dopamine D4 receptor genes (DRD4), dopamine D5 receptor genes (DRD5), and dopamine transporter gene (DAT) (9). Intrauterine alterations in gonadal hormones, especially an increased testosterone level have been implied in the pathogenesis of physical differences in children with attention deficit hyperactivity disorder. This factor also plays a role in the etiology of the disease itself (15). It has been reported that children exposed to high levels of testosterone during intrauterine period have an increased ADHD prevalence (16), and higher prenatal androgen levels also cause differences in hand measurements (17). New studies suggested that the 2D:4D is determined not by prenatal testosterone but by the balance of PT to PE signaling $(18,6)$. Also, a possible role of estrogen levels in development of hyperactivity has also been explored and it has been reported that estrogen's action as a dopamine receptor agonist may be responsible from sexual differences in symptoms of ADHD (9,10).

The aim of our study was to perform hand and finger measurements and determine the ADHD-related finger ratios, particularly 2D:4D ratio, in a Turkish patient population treated for attention deficit and hyperactivity disorder, and to compare the results of this population with those of healthy individuals. We also aimed to investigate whether this ratio may be utilized as an easy-to-use parameter for initial diagnosis in clinical practice.

\section{Methods}

Subjects and Study procedure: This study was a cross-sectional comparative study investigating hand and finger measurements of a total of 540 subjects, of whom 436 (196 females, 240 males) between 7-17 years old were used as the control group and 104 (27 females, 77 males) were subjects with attention deficit and hyperactivity disorder (ADHD) diagnosed by DSM IV criteria and treated at a faculty of medicine department of child psychiatry used as the patient group (9). The local ethics committee approved the study and an informed consent was obtained from each patient's parents. Twenty-five (24\%) patients were of the 8 years of age group and they form the largest age group. This was followed by the children of 10 years of age $(n=17,16.3 \%)$ and the children of 7 years of age $(n=15,14.4 \%)$. The study sample was selected from a population over 7 years of age, since the diagnosis of ADHD is made only after 7 years of age.

The measurements of the first, second, third, fourth, and fifth finger were made on the palmar face of the hand by determining the distance between the basal line at the proximal part of finger and the pulpa (19).

The measurements were carried out with a digital compass that was a direct measurement method (20). Both left and right hand measurements were performed in all subjects in sequence. The subjects were asked to place their hand on a flat surface in a tense position in a way that the palmar face of the hand will face the examiner and the fingers is in abducted position. All measurements were done in sequence by the same examiner.

Statistical Analysis: Data of the measurements were recorded in Microsoft Excel Working Page by the researcher and using the SPSS 15.0 program via Mann-Whitney U test.

\section{Results}

There was a significant difference between the children with ADHD and the controls with respect to the finger ratio of right hand $(\mathrm{p}<0.05)$ (Table 1). The 2D:4D ratio of right hand was $0.96 \pm 0.03$ in the ADHD group and $0.99 \pm 0.04$ in the control group $(p<0.05)$ (Table 1). Comparison of the finger ratio of left hand revealed a significant difference between the two groups in terms of $2 \mathrm{D}: 4 \mathrm{D}$ and $4 \mathrm{D}: 5 \mathrm{D}$ ratios $(p<0.05)$ (Table 1). The 2D:4D ratios of the patient and control groups were $1.01 \pm 0.04$ and $1.00 \pm 0.03$, respectively $(\mathrm{p}<0.05) \quad($ Table 1$)$. Hence, there were significant differences between the children with attention deficit and hyperactivity disorder and the control group children with respect to the 2D:4D ratios of both left and right hand $(\mathrm{p}<0.05)$ (Table 1).

The attention deficit hyperactivity disorder group and the male control group also differed significantly with respect to the $2 \mathrm{D}: 4 \mathrm{D}, 2 \mathrm{D}: 5 \mathrm{D}, 3 \mathrm{D}: 4 \mathrm{D}$, and $3 \mathrm{D}: 5 \mathrm{D}$ ratios of right hand and the $2 \mathrm{D}: 4 \mathrm{D}$ and $2 \mathrm{D}: 5 \mathrm{D}$ ratios of left hand $(p<0.05)$ (Table 2). The male children 
with ADHD had a significant 2D:4D right hand ratio of $0.95 \pm 0.03(\mathrm{p}<0.05)$ while the control group had $0.98 \pm 0.04(\mathrm{p}<0.05)$ (Table 2$)$. The male children with ADHD had a significant 2D:4D left hand ratio of $1.00 \pm 0.04(\mathrm{p}<0.05)$, and the control group had $0.99 \pm 0.04(\mathrm{p}<0.05)$ (Table 2).

There was a significant difference between the female children with attention deficit and hyperactivity disorder and the female control group subjects with respect to all finger ratios of right hand (Table 3). The ADHD group had 2D:4D ratio of $0.96 \pm 0.04$ and the control group had 2D:4D ratio of $1.00 \pm 0.04$ $(p<0.05)$ (Table 3$)$. The same groups had significant differences between 2D:4D ratio and 4D:5D ratios of left hand $(\mathrm{p}<0.05)$ (Table 3$)$ The $2 \mathrm{D}: 4 \mathrm{D}$ ratio of left hand was found $1.02 \pm 0.02$ in the ADHD group and $1.00 \pm 0.03$ in the control group $(\mathrm{p}<0.05)$ (Table 3).

Table 1. The comparison of children with ADHD and healthy children's left and right hand digit ratios

\begin{tabular}{|c|c|c|c|c|c|c|c|c|c|c|}
\hline \multirow[b]{3}{*}{$\begin{array}{l}\text { Ratios of } \\
\text { digit lengths }\end{array}$} & \multicolumn{5}{|c|}{ Right hand measurements } & \multicolumn{5}{|c|}{ Left hand measurements } \\
\hline & \multicolumn{2}{|c|}{ Group of ADHD } & \multicolumn{2}{|c|}{ Group of control } & \multirow[b]{2}{*}{$\mathrm{p}^{*}$} & \multicolumn{2}{|c|}{ Group of ADHD } & \multicolumn{2}{|c|}{ Group of control } & \multirow[b]{2}{*}{$\mathrm{p}^{*}$} \\
\hline & $\mathrm{X} \pm \mathrm{SD}$ & $\begin{array}{l}\text { Median } \\
\text { (min- } \\
\max )\end{array}$ & $\mathrm{X} \pm \mathrm{SD}$ & $\begin{array}{l}\text { Median } \\
(\min - \\
\max )\end{array}$ & & $\mathrm{X} \pm \mathrm{SD}$ & $\begin{array}{l}\text { Median } \\
\text { (min- } \\
\max )\end{array}$ & $\mathrm{X} \pm \mathrm{SD}$ & $\begin{array}{l}\text { Median } \\
\text { (min- } \\
\max )\end{array}$ & \\
\hline $2 \mathrm{D}: 3 \mathrm{D}$ & $0.90 \pm 0.03$ & $\begin{array}{c}0.90 \\
(0.7-0.9)\end{array}$ & $0.92 \pm .0 .03$ & $\begin{array}{c}0.91 \\
(0.7-1.0)\end{array}$ & 0.005 & $0.92 \pm 0.03$ & $\begin{array}{c}0.92 \\
(0.8-1.0)\end{array}$ & $0.92 \pm 0.03$ & $\begin{array}{c}0.92 \\
(0.8-1.0)\end{array}$ & 0.101 \\
\hline 2D:4D & $0.96 \pm 0.03$ & $\begin{array}{c}0.95 \\
(0.8-1.1)\end{array}$ & $0.99 \pm 0.04$ & $\begin{array}{c}0.98 \\
(0.8-1.2)\end{array}$ & 0.001 & $1.01 \pm 0.04$ & $\begin{array}{c}1.01 \\
(0.9-1.1)\end{array}$ & $1.00 \pm 0.03$ & $\begin{array}{c}1.00 \\
(0.8-1.1)\end{array}$ & 0.004 \\
\hline 2D:5D & $1.15 \pm 0.06$ & $\begin{array}{c}1.14 \\
(1.0-1.4) \\
\end{array}$ & $1.20 \pm 0.07$ & $\begin{array}{c}1.20 \\
(0.8-1.4)\end{array}$ & 0.001 & $1.22 \pm 0.06$ & $\begin{array}{c}1.21 \\
(1.0-1.4) \\
\end{array}$ & $1.21 \pm 0.06$ & $\begin{array}{c}1.20 \\
(0.9-1.4) \\
\end{array}$ & 0.824 \\
\hline $3 \mathrm{D}: 4 \mathrm{D}$ & $1.05 \pm 0.03$ & $\begin{array}{c}1.05 \\
(0.9-1.1)\end{array}$ & $1.07 \pm 0.03$ & $\begin{array}{c}1.07 \\
(0.9-1.3)\end{array}$ & 0.005 & $1.09 \pm 0.03$ & $\begin{array}{c}1.09 \\
(1.0-1.2)\end{array}$ & $1.08 \pm 0.03$ & $\begin{array}{c}1.08 \\
(0.9-1.3)\end{array}$ & 0.235 \\
\hline 3D:5D & $1.27 \pm 0.06$ & $\begin{array}{c}1.26 \\
(1.1-1.5)\end{array}$ & $1.30 \pm 0.07$ & $\begin{array}{c}1.30 \\
(0.9-1.6)\end{array}$ & 0.001 & $1.31 \pm 0.07$ & $\begin{array}{c}1.30 \\
(1.1-1.6)\end{array}$ & $1.31 \pm 0.06$ & $\begin{array}{c}1.31 \\
(1.0-1.6)\end{array}$ & 0.076 \\
\hline 4D:5D & $1.20 \pm 0.06$ & $\begin{array}{c}1.19 \\
(1.0-1.4)\end{array}$ & $1.21 \pm 0.06$ & $\begin{array}{c}1.21 \\
(0.8-1.6)\end{array}$ & 0.020 & $1.20 \pm 0.06$ & $\begin{array}{c}1.19 \\
(1.0-1.4)\end{array}$ & $1.21 \pm 0.06$ & $\begin{array}{c}1.21 \\
(0.9-1.5)\end{array}$ & 0.004 \\
\hline
\end{tabular}

*:Test of Mann Whitney U. X: average. SD. Standard deviation

Table 2. The comparison of children with ADHD and healthy children's left and right hand digit ratios in male group

\begin{tabular}{|c|c|c|c|c|c|c|c|c|c|c|}
\hline & \multicolumn{4}{|c|}{ Right hand measurements } & \multicolumn{5}{|c|}{ Left hand measurements } & \multirow[b]{3}{*}{$\mathrm{p}^{*}$} \\
\hline & \multicolumn{2}{|c|}{ Group of ADHD } & \multicolumn{2}{|c|}{ Group of control } & \multirow[b]{2}{*}{$\mathrm{p}^{*}$} & \multicolumn{2}{|c|}{ Group of ADHD } & \multicolumn{2}{|c|}{ Group of control } & \\
\hline $\begin{array}{l}\text { Ratios } \\
\text { of } \\
\text { finger } \\
\text { lengths }\end{array}$ & $\mathrm{X} \pm \mathrm{SD}$ & $\begin{array}{c}\text { Median } \\
(\min -\max )\end{array}$ & $\mathrm{X} \pm \mathrm{SD}$ & $\begin{array}{c}\text { Median } \\
(\min -\max )\end{array}$ & & $\mathrm{X} \pm \mathrm{SD}$ & $\begin{array}{c}\text { Median } \\
(\min -\max )\end{array}$ & $\mathrm{X} \pm \mathrm{SD}$ & $\begin{array}{c}\text { Median } \\
(\min -\max )\end{array}$ & \\
\hline $2 \mathrm{D}: 3 \mathrm{D}$ & $0.90 \pm 0.036$ & $\begin{array}{c}0.90 \\
(0.78-0.99)\end{array}$ & $0.91 \pm 0.03$ & $\begin{array}{c}0.91 \\
(0.79-1.08)\end{array}$ & 0.057 & $0.920 \pm 0.04$ & $\begin{array}{c}0.92 \\
(0.82-1.05)\end{array}$ & $0.92 \pm 0.03$ & $\begin{array}{c}0.92 \\
(0.85-1.04)\end{array}$ & 0.109 \\
\hline $2 \mathrm{D}: 4 \mathrm{D}$ & $0.95 \pm 0.03$ & $\begin{array}{c}0.95 \\
(0.88-1.05)\end{array}$ & $0.98 \pm 0.04$ & $\begin{array}{c}0.97 \\
(0.85-1.20)\end{array}$ & 0.001 & $1.00 \pm 0.04$ & $\begin{array}{c}0.99 \\
(0.90-1.12)\end{array}$ & $0.99 \pm 0.04$ & $\begin{array}{c}0.99 \\
(0.89-1.18)\end{array}$ & 0.017 \\
\hline 2D:5D & $1.15 \pm 0.06$ & $\begin{array}{c}1.14 \\
(1.02-1.47)\end{array}$ & $1.18 \pm 0.07$ & $\begin{array}{c}1.18 \\
(0.84-1.41)\end{array}$ & 0.001 & $1.22 \pm 0.07$ & $\begin{array}{c}1.21 \\
(1.02-1.43)\end{array}$ & $1.20 \pm 0.07$ & $\begin{array}{c}1.19 \\
(0.95-1.47)\end{array}$ & 0.030 \\
\hline $3 \mathrm{D}: 4 \mathrm{D}$ & $1.05 \pm 0.03$ & $\begin{array}{c}1.05 \\
(0.97-1.15)\end{array}$ & $1.07 \pm 0.04$ & $\begin{array}{c}1.07 \\
(0.94-1.33)\end{array}$ & 0.002 & $1.08 \pm 0.03$ & $\begin{array}{c}1.08 \\
(1.01-1.21)\end{array}$ & $1.08 \pm 0.03$ & $\begin{array}{c}1.07 \\
(0.94-1.32)\end{array}$ & 0.179 \\
\hline 3D:5D & $1.27 \pm 0.07$ & $\begin{array}{c}1.26 \\
(1.15-1.54)\end{array}$ & $1.29 \pm 0.07$ & $\begin{array}{c}1.29 \\
(0.95-1.55)\end{array}$ & 0.001 & $1.32 \pm 0.07$ & $\begin{array}{c}1.30 \\
(1.19-1.68)\end{array}$ & $1.30 \pm 0.07$ & $\begin{array}{c}1.30 \\
(1.06-1.61)\end{array}$ & 0.297 \\
\hline 4D:5D & $1.20 \pm 0.06$ & $\begin{array}{c}1.19 \\
(1.09-1.48)\end{array}$ & $1.21 \pm 0.06$ & $\begin{array}{c}1.21 \\
(.81-1.38)\end{array}$ & 0.078 & $1.21 \pm 0.06$ & $\begin{array}{c}1.20 \\
(1.06-1.49)\end{array}$ & $1.20 \pm 0.06$ & $\begin{array}{c}1.20 \\
(0.95-1.56)\end{array}$ & 0.795 \\
\hline
\end{tabular}

${ }^{*}:$ Test of Mann Whitney U. X: average. SD. Standard deviation 
Table 3. The comparison of children with ADHD and healthy children's left and right hand digit ratios in female group

\begin{tabular}{|c|c|c|c|c|c|c|c|c|c|c|}
\hline & \multicolumn{5}{|c|}{ Right hand measurements } & \multicolumn{5}{|c|}{ Left hand measurements } \\
\hline & \multicolumn{2}{|c|}{ Group of ADHD } & \multicolumn{2}{|c|}{ Group of control } & \multirow[b]{2}{*}{$\mathrm{p}^{*}$} & \multicolumn{2}{|c|}{ Group of ADHD } & \multicolumn{2}{|c|}{ Group of control } & \multirow[b]{2}{*}{$\mathrm{p}^{*}$} \\
\hline $\begin{array}{l}\text { Ratios } \\
\text { of } \\
\text { finger } \\
\text { lengths }\end{array}$ & $\mathrm{X} \pm \mathrm{SD}$ & $\begin{array}{c}\text { Median } \\
(\min -\max )\end{array}$ & $\mathrm{X} \pm \mathrm{SD}$ & $\begin{array}{c}\text { Median } \\
(\min -\max )\end{array}$ & & $\mathrm{X} \pm \mathrm{SD}$ & $\begin{array}{c}\text { Median } \\
(\min -\max )\end{array}$ & $\mathrm{X} \pm \mathrm{SD}$ & $\begin{array}{c}\text { Median } \\
(\min -\max )\end{array}$ & \\
\hline $2 \mathrm{D}: 3 \mathrm{D}$ & $0.90 \pm 0.02$ & $\begin{array}{c}0.90 \\
(0.85-0.96)\end{array}$ & $0.92 \pm 0.031$ & $\begin{array}{c}0.9248 \\
(0.85-1.01)\end{array}$ & & $0.93 \pm 0.02$ & $\begin{array}{c}0.93 \\
(0.89-0.99)\end{array}$ & $0.92 \pm 0.03$ & $\begin{array}{c}0.92 \\
(0.83-1.01)\end{array}$ & 0.101 \\
\hline 2D:4D & $0.96 \pm 0.04$ & $\begin{array}{c}0.96 \\
(0.91-1.12) \\
\end{array}$ & $1.00 \pm 0.04$ & $\begin{array}{c}1.0036 \\
(0.89-1.09)\end{array}$ & 0.001 & $1.02 \pm 0.021$ & $\begin{array}{c}1.02 \\
(0.98-1.07)\end{array}$ & $1.00 \pm 0.03$ & $\begin{array}{c}1.00 \\
(0.89-1.11)\end{array}$ & 0.004 \\
\hline $2 \mathrm{D}: 5 \mathrm{D}$ & $1.15 \pm 0.04$ & $\begin{array}{c}1.16 \\
(1.09-1.23)\end{array}$ & $1.22 \pm 0.07$ & $\begin{array}{c}1.2204 \\
(1.04-1.48)\end{array}$ & 0.001 & $1.21 \pm 0.04$ & $\begin{array}{c}1.21 \\
(1.11-1.32)\end{array}$ & $1.22 \pm 0.06$ & $\begin{array}{c}1.21 \\
(1.05-1.47)\end{array}$ & 0.824 \\
\hline $3 \mathrm{D}: 4 \mathrm{D}$ & $1.06 \pm 0.03$ & $\begin{array}{c}1.06 \\
(1.01-1.16)\end{array}$ & $1.08 \pm 0.03$ & $\begin{array}{c}1.0841 \\
(0.98-1.17)\end{array}$ & 0.005 & $1.10 \pm 0.03$ & $\begin{array}{c}1.10 \\
(1.04-1.15)\end{array}$ & $1.09 \pm 0.03$ & $\begin{array}{c}1.09 \\
(0.95-1.21)\end{array}$ & 0.235 \\
\hline $3 \mathrm{D}: 5 \mathrm{D}$ & $1.27 \pm 0.06$ & $\begin{array}{c}1.26 \\
(1.18-1.45)\end{array}$ & $1.32 \pm 0.06$ & $\begin{array}{c}1.3211 \\
(1.15-1.66)\end{array}$ & 0.001 & $1.30 \pm 0.06$ & $\begin{array}{c}1.30 \\
(1.18-1.45)\end{array}$ & $1.33 \pm 0.06$ & $\begin{array}{c}1.32 \\
(1.12-1.59)\end{array}$ & 0.076 \\
\hline 4D:5D & $1.19 \pm 0.05$ & $\begin{array}{c}1.19 \\
(1.01-1.34)\end{array}$ & $1.22 \pm 0.06$ & $\begin{array}{c}1.2171 \\
(1.09-1.62)\end{array}$ & 0.020 & $1.18 \pm 0.04$ & $\begin{array}{c}1.18 \\
(1.10-1.31)\end{array}$ & $1.21 \pm 0.05$ & $\begin{array}{c}1.21 \\
(1.04-1.41)\end{array}$ & 0.004 \\
\hline
\end{tabular}

*:Test of Mann Whitney U. X: average. SD. Standard deviation

\section{Discussion}

Studies on subjects of different races, socioeconomic levels, and geographical regions have shown that $3 \%$ to $6 \%$ of school age children have attention deficit and hyperactivity disorder (9). According to the DSM criteria published by the American Society of Psychiatry the rate of the disorder is somewhere between 3-5\% (9). Studies considering over activity as an indicator of the disease have reported that the disease has an incidence of $41.9 \%$ in the $7-8$ years age group and $26.7 \%$ in the 12 years age group (9). In USA the incidence of the disorder is between $2 \%$ and $20 \%$ in school age children and $3 \%$ and $5 \%$ in children before adolescence (9). According to DSM IV criteria of the American Society of Psychiatry, ADHD is more commonly observed in the 7-8 years age group. According to surveys from United Kingdom, the prevalence of the disease is below $1 \%$ (9). In Turkey, on the other hand, the prevalence of the disease has been reported between $21.4 \%$ and $25.9 \%$, with boys being affected three times more than girls (9). Consistent with literature data, our study included more males than females with ADHD. According to our results, the prevalence of the disorder was $14.4 \%$ in the 7 years age group, $24.0 \%$ in the 8 years age group, $10.6 \%$ in the 9 years age group, and $16.3 \%$ in the 10 years age group. Hence, our results were consistent with the rates reported by the American Society of Psychiatry and with other studies from our country.

There are differences between 2D:4D ratio of the right and left hand in the two sexes. Males had a mean 2D:4D ratio of 0.98 , with fourth finger being longer than the second. Females, on the other hand, have 2D:4D ratio equal to or greater than 1 . This difference becomes evident at 2 years of age at the earliest. This ratio may be increased by high estrogen, luteinizing hormone, and prolactin levels (8).

Intrauterine gonadal steroids are necessary for the development of genital organs. Congenital adrenal hyperplasia is a clinical picture associated with deficiency of the enzyme 21 hydroxylase characterized by an excessive increase in androgen levels in utero. In this disorder, the external genital organs of a female fetus resemble to those of a male fetus. The 2D:4D ratio has been found lower in persons with congenital adrenal hyperplasia (21-24). Hyperandrogenism may lead to a low 2D:4D ratio in females (25). Also, a recent study reported that in males with Klinefelter's syndrome, the mean 2D:4D values were similar to those found in female population norms (26).

Lutchmaya et al., (27) in a study in 2004, studied amniotic fluid for a possible relationship between 2D:4D ratio and fetal estrogen and fetal testosterone. Depending on gender, there was a negative correlation between the $2 \mathrm{D}: 4 \mathrm{D}$ ratio of right hand and fetal estrogen and fetal testosterone. A higher prenatal testosterone level, and hence a lower 2D:4D ratio, have been linked to left hand preference and a higher sperm count in men (27).

Some researchers have investigated the 2D:4D ratio in male children with various disorders including 
autism, Asperger syndrome, attention deficit and hyperactivity disorder, progressive developmental disorder, and anxiety disorder (4, 28). A lower 2D:4D ratio was observed in children with autism or Asperger syndrome compared to those with anxiety disorder. Children with autism or Asperger syndrome also exhibited a lower 2D:4D ratio compared to normal children. Under the light of this information, it has been suggested that higher fetal androgen levels not only cause autism, but also other psychiatric disorders (4). It has been reported that children with autism have a shorter fourth finger than second finger (29).

Martel investigated the relationship between 2D:4D ratio and a lower consciousness-awareness level and symptoms of attention deficit and hyperactivity disorder. Both male and female children with attention deficit and hyperactivity disorder had a more masculine finger length ratio (a lower 2D:4D ratio) and a lower consciousness-awareness level compared to the control group (16).

Our study group revealed a statistically meaningful difference between the ADHD and their controls in 2D:4D ratio of their right hand and the 2D:4D and 4D:5D ratios of their left hand. The male ADHD subjects and controls also demonstrated significant difference in their 2D:4D, 2D:5D, 3D:4D, and 3D:5D ratios of the right hand and the 2D:4D and 2D:5D ratios of the left hand. Especially, ADHD boys had a more feminized 2D:4D left hand ratio than the controls. While, there was a significant difference in all finger ratios of the right hand and the 2D:4D and 4D:5D ratios of the left hand between the ADHD girls and their controls. Thus, the more masculine 2D:4D right hand ratio was observed in ADHD girls.

Attention deficit and hyperactivity disorder is an important condition due to the facts that it is a common curable condition that may lead to psychiatric and social deterioration when left untreated and represents a highly permanent disorder extending from the preschool period well into adulthood with inherent developmental abnormalities. Early diagnosis and treatment of this and some other psychiatric diseases of childhood is of paramount importance.

The findings of our study suggest that ADHD and other psychiatric disorders of childhood may be diagnosed at an early period with the help of anthropological measurements. This, in turn, will hopefully allow timely treatment of affected individuals.

\section{References}

1. Wilson FR. 1998. The Hand. New York: Pantheon Books.

2. Dollé P, Izpisúa-Belmonte JC, Boncinelli E, Duboule D. The Hox- 4.8 gene is localized at the 5 ' extremity of the Hox-4 complex and is expressed in the most posterior parts of the body during development. Mech Dev 1991; 36: 3-13.

3. Dollé P, Izpisúa-Belmonte JC, Brown JM, Tickle C, Duboule D. HOX-4 genes and the morphogenesis of mammalian genitalia. Genes Dev 1991; 5: 1767-1767.

4. Bruin EI, Verheij F, Wiegmann T, Ferdinand RF. Differences in finger length ratio between males with autism, pervasive developmental disorder-not otherwise specified, ADHD, and anxiety disorders. Dev Med Child Neurol 2006; 48: 962-965.

5. Waldman ID, Gizer IR. 2006. The genetics of attention deficit hyperactivity disorder. Clin Psychol Rev 26: 396-432.

6. Zheng Z, Cohn MJ. Developmental basis of the sexually dimorphic digit ratio. Proc Natl Acad Sci USA 2011; 108: 16289-16294.

7. Pheasent S. Anthropometrics: an introduction. United Kingdom: British Standard Intitution; pp1990; 18-9.

8. Manning JT, Scutt D, Wilson J, Lewis-Jones DI. The ratio of second to fourth digit ratio: a predictor of sperm numbers and concentrations of testosterone, luteinizing hormone and oestrogen. Hum Reprod 1998; 13: 3000-3004.

9. Şenol S, İşeri E, Koçkar Aİ. 2005. Dikkat Eksikliği/Hiperaktivite Bozukluğu. Ankara: HYB Yayıncıllk (Türkçe)

10. Semerci B, Turgay A. 2010. Bebeklikten Erişkinliğe Dikkat Eksikliği Hiperaktivite Bozukluğu. 4. Basım. İstanbul: Alfa Yayınları (Türkçe)

11. Williams JHG, Greenhalgh KD, Manning JT. Second to fourth finger ratio and possible precursors of developmental psychopathology in preschool children. Early Hum Dev 2003; 72: 57-65.

12. Bailey Aa, Hurd PL. Finger length ratio (2D:4D) correlates with physical aggression in men but not in women. Biol Psychol 2005; 68: 215-222.

13. Stevenson JC, Everson PM, Williams DC, Hipskind G, Grimes M, Mahoney ER. Attention deficit/hyperactivity disorder (DEHB) symptoms and digit ratios in a college sample. Am J Hum Biol 2007; 19: 41-50.

14. McFadden D, Westhafer JG, Pasanen EG, Carlson CL, Tucker DM. Physiological evidence of hypermasculinization in boys with the inattentive type of attention deficit/hyperactivity disorder (ADHD). Clin Neurosci Res 2005; 5: 233-245.

15. Martel MM, Gobrogge KL, Breedlove SM, Nigg JT. Masculinized finger-length ratios of boys, but not girls, are associated with attentiondeficit/hyperactivity disorder. Behav Neurosci. 2008; 122: $273-281$. 
16. Martel MM. Conscientiousness as a mediator of the association between masculinized finger-length ratios and attention deficit/hyperactivity disorder (DEHB). J Child Psychol Psychiatry 2009; 50: 790-798.

17. Berenbaum SA, Bryk KK, Nowak N, Quigley CA, Moffat S. Fingers as a marker of prenatal androgen exposure. Endocrinology 2009; 150: 5119-5124.

18. Manning JT. Resolving the role of prenatal sex steroids in the development of digit ratio. Proc Natl Acad Sci USA 2011; 108: 16143-16144.

19. Martin R, Saller K. Lehrbuch Der Anthropologie. Stuttgard: Gustav Fischer Cerlag 2003; 1058-1065.

20. Almasry SM, El Domiaty MA, Algaidi SA, Elbastawisy YM, Safwat MD. Index to ring digit ratio in Saudi Arabia at Almadinah Almonawarah province: a direct and indirect measurement study. J Anat 2011; 218: 202-208.

21. Ökten A, Kalyoncu M, Yarıs N. The ratio of secondand fourth- digit lengths and congenital adrenal hyperplasia due to 21-hydroxylase deficiency. Early Hum Dev 2002; 70: 47-54.

22. Buck JJ, Williams RM, Hughes IA, Acerini CL. Inutero androgen exposure and 2nd to 4th digit length ratio- comparisons between healthy controls and females with classical congenital adrenal hyperplasia. Hum Reprod 2003; 18: 976-979.
23. McFadden D, Loehlin JC, Breedlove SM, Lippa RA, Manning JT, Rahman Q. Reanalysis of Five Studies on Sexual Orientation and the Relative Length of the 2nd and 4th Fingers (the 2D:4D Ratio). Arch Sex Behav 2005; 34: 341-356.

24. Malas MA, Dogan S, Evcil EH, Desdicioglu K. Fetal development of the hand, digits and digit ratio (2D:4D). Early Hum Dev 2006; 82: 469-475.

25. Zabuliene L, Tutkuviene J. Body composition and polycystic ovary syndrome. Medicina (Kaunas) 2010; 46: 142-157.

26. Manning JT, Kilduff LP, Trivers R. Digit ratio (2D:4D) in Klinefelter's syndrome. Andrology 2013; 1: 94-99.

27. Lutchmaya S, Baron-Cohen S, Raggatt P, Knickmeyer R, Manning JT. 2nd to 4th digit ratios, fetal testosterone and estradiol. Early Hum Dev 2004; 77: 23-28.

28. Romero-Martínez Á, Polderman TJC, GonzálezBono E, Moya-Albiol L. Masculinization in Parents of Offspring With Autism Spectrum Disorders Could Be Involved in Comorbid ADHD Symptoms. J Atten Disord 2017; 21: 938-943.

29. Manning JT, Baron-Cohen S, Wheelwright S, Sanders G. The 2nd to 4th digit ratio and autism. Dev Med Child Neurol 2001; 43: 160-164. 